\title{
HOMENAGEM AO PROFESSOR WELLINGTON MAROTA BARBOSA
}

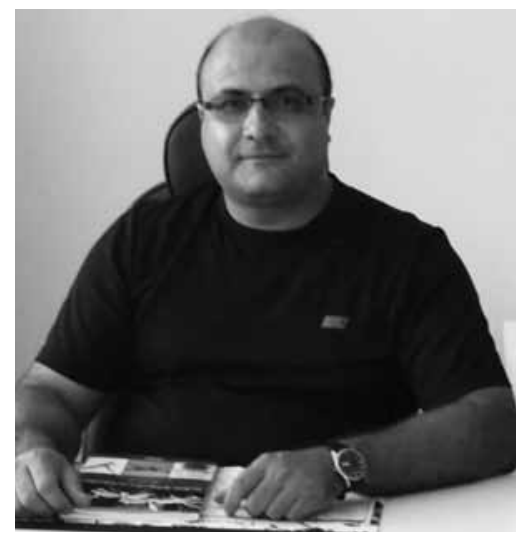

"O IFSULDEMINAS está crescendo no âmbito do ensino, pesquisa, extensão e inovação, $e$ tenho orgulho de poder contribuir com esse avanço, principalmente por meio da revisão de artigos do nosso periódico institucional, que é muito importante no reconhecimento e na divulgação das pesquisas que estão sendo desenvolvidas."

O professor Wellington Marota Barbosa é engenheiro-agrônomo, formado pela Universidade Federal de Viçosa (UFV) no ano de 1997, traçou sua carreira desde o momento em que ingressou na Universidade, dedicando-se às atividades de ensino e pesquisa. Assim que se graduou, ingressou no Mestrado em Botânica na mesma Instituição e, logo em seguida, no Doutorado, também na UFV, dessa vez na área de Fitotecnia, enfocando o tema café, com dissertação sobre Embriogênese somática em cafés arábica e robusta.

No período de 2003 a 2006 atuou como Bolsista de Desenvolvimento Científico/Tecnológico pelo PNP\&DCafé (Programa Nacional de Pesquisa e Desenvolvimento do Café), pela Embrapa Café, no Centro Regional de Desenvolvimento Rural Centro Serrano - INCAPER, desenvolvendo trabalhos com Marcadores Moleculares em café Conilon.
No ano de 2006 ingressou na carreira de magistério superior no CEFET Bambuí, sendo redistribuído, em 2007, para a antiga Escola Agrotécnica Federal de Machado, atual IFSULDEMINAS campus Machado. Desde então atua como docente e, atualmente, ministra disciplinas nas áreas de Biotecnologia, Fisiologia Vegetal, Cafeicultura, Fisiologia do Cafeeiro e Metodologia da Pesquisa. Desenvolve e coordena vários projetos envolvendo cultura de tecidos vegetais, fisiologia vegetal e biotecnologia, sendo coordenador do Laboratório de Biotecnologia do IFSULDEMINAS campus Machado.

Atua ainda como coordenador do Núcleo de Inovação Tecnológica do IFSULDEMINAS, onde trabalha no desenvolvimento da cultura da inovação tecnológica na Instituição. Contribui como membro do corpo editorial da Revista AgroGeoAmbiental, além de ser colaborador do periódico Horticultura Brasileira e Bioscience Journal, como revisor, desde 2011. 